\title{
Indian childhood cirrhosis in the United Kingdom
}

\author{
H J KLASS, J K KELLY, AND T W WARNES* \\ From the University Departments of Gastroenterology and Pathology, Manchester Royal Infirmary, \\ Manchester
}

SUMmaRY Two young brothers with cirrhosis are reported. They are the issue of a first-cousin marriage between Bangladeshi parents. The older boy was born in Bangladesh, the younger in England. A diagnosis of Indian childhood cirrhosis (ICC) was made on the basis of the clinical features and the liver histology. The younger brother represents the first example of this disease in a patient born in the United Kingdom.

Indian childhood cirrhosis is considered to be a welldefined childhood liver disease, occurring exclusively in India, Bangladesh, Sri Lanka, and Burma. The characteristic features, apart from its geographical distribution, are onset in early childhood, a latent period of abdominal pain and diarrhoea before the development of jaundice, hepatosplenomegaly, and a typical liver histology with generalised hepatocellular damage, creeping pericellular fibrosis, poor regeneration, and florid deposits of Mallory's hyaline. A familial incidence of up to $39 \%{ }^{1}$ has been reported. Within a family, siblings are preferentially affected, the first child most commonly $(24.4 \%)$ followed by the second $(19.8 \% .)^{2}$ Boys are affected more commonly than girls. ${ }^{3}$ The aetiology is unknown. The disease has not so far been reported in a patient born in the Western Hemisphere.

\section{Case reports}

CASE 1

Abdul, the older brother, was conceived in the UK but born in Bangladesh; he arrived in the UK aged 4 years. He presented to the ENT department of the Manchester Royal Infirmary in December 1974 with a three year history of epistaxes. He was first seen by us in April 1977, aged 10 years, with a history of fatigue and jaundice for one year and of intermittent central abdominal pain and diarrhoea 'for some years' before this. When admitted in May 1977 he was in acute liver failure with encephalopathy; finger and toe clubbing, facial telangiectases, hepatosplenomegaly, ascites and ankle oedema were

\footnotetext{
*Address for correspondence: Dr T W Warnes, Liver Section, University Department of Gastroenterology, Manchester Royal Infirmary, Oxford Road, Manchester M13 9WL.

Received for publication 2 November 1979
}

present and he was below the third centile for height and weight. Kayser-Fleischer rings were absent on slit-lamp examination.

Haemoglobin $(\mathrm{Hb})$ concentration was 7.5 $\mathrm{g} / \mathrm{dl}$ and platelet count $82 \times 10^{9} / 1\left(82000 / \mathrm{mm}^{3}\right)$. The total serum bilirubin was $49 \mu \mathrm{mol} / \mathrm{l}$ $(2.9 \mathrm{mg} \%$ ), aspartate transaminase 329 lU/I (normal $<40 \mathrm{IU} / \mathrm{l}$ ), alkaline phosphatase $591 \mathrm{IU} / 1$ (normal $<100 \mathrm{IU} / \mathrm{l})$ most of which was shown electrophorectically ${ }^{4}$ to be of bone origin, albumin was $19 \mathrm{~g} / 1(1.9 \mathrm{~g} / 100 \mathrm{ml})$ and globulin $50 \mathrm{~g} / 1(5 \mathrm{~g} /$ $100 \mathrm{ml})$. Serum calcium was $1.76 \mathrm{mmol} / \mathrm{l} \quad(7.04$ $\mathrm{mg} / 100 \mathrm{ml}$ ) and inorganic phosphate $0.59 \mathrm{mmol} / \mathrm{l}$ $(1.8 \mathrm{mg} / 100 \mathrm{ml})$. The serum parathormone (PTH) level was raised at $1.6 \mathrm{ng} / \mathrm{ml}$ (normal $0 \cdot 2-0.7 \mathrm{ng} / \mathrm{ml}$ ). The prothrombin time was 27 seconds (control 14 seconds) and was not correctable by vitamin $\mathrm{K}$ or fresh frozen plasma, precluding a percutaneous liver biopsy. A liver scan with pyridoxilidene glutamate showed gross hepatocellular dysfunction. A technetium sulphur colloid liver scan showed a cirrhotic pattern with very poor hepatic uptake and markedly increased uptake by the spleen and bone marrow. Extrahepatic obstruction was excluded by grey-scale ultrasound scan; there was no evidence of a choledochal cyst. The serum caeruloplasmin was 0.36 OD units (copper oxidase method, normal range $0 \cdot 2-0 \cdot 5$ OD units) and serum copper $14.6 \mu \mathrm{mol} / 1(90 \mu \mathrm{g} /$ $100 \mathrm{ml})$. The serum iron was $2 \cdot 3 \mu \mathrm{mol} / \mathrm{l} \quad(12 \cdot 6$ $\mathrm{mg} / 100 \mathrm{ml}$ ) and iron binding capacity $37 \cdot 2 \mu \mathrm{mol} / \mathrm{l}$ $(208 \mathrm{mg} / 100 \mathrm{ml})$. The smooth muscle and antimitochondrial antibody tests and anti-nuclear factor were negative. Hepatitis $B$ surface antigen and antibody (HBsAg and $\mathrm{HBsAb}$ ) were absent by radioimmunoassay (RIA). The serum $\alpha_{1}$-anti-trypsin concentration was $100 \%$ of average normal. The sweat electrolyte concentrations were normal. 
Galactose-1-phosphate uridyl transferase was detected in normal amounts in red cells. WR, toxoplasma dye test, and specific viral antibody tests were negative. The serum $\alpha$-foetoprotein concentration was $<10 \mathrm{ng} / \mathrm{ml}$ (RIA). Bone marrow examination showed no infiltration with abnormal cells. Urinary mucopolysaccharides were not increased. Urinary porphyrins were absent. The ferric chloride test ${ }^{5}$ on urine was negative. There was a non-specific aminoaciduria on chromatography with no evidence of tyrosinaemia. The 24-hour urinary copper output was $1 \cdot 1 \mu \mathrm{mol}(70 \mu \mathrm{g})$. Hereditary fructose intolerance was excluded by the absence of reducing sugars in the urine, together with a normal fructose tolerance test. Red and white cell enzyme assays revealed no evidence of glycogen storage disorders types 3, 4, 6 or 8. Chromosome studies showed a normal male karyotype (46 XY).

The hepatic decompensation responded to bed rest, neomycin, and diuretics, but, when he was readmitted in January 1978, he had developed a hepatic foetor and marked gynaecomastia, the ascites had returned, the liver had become impalpable, and he was found to have a Pasteurella multocida septicaemia which responded to antibiotic therapy. His last admission to hospital was in April 1978, when Escherichia coli was cultured from the ascitic fluid and Citrobacter freundii from his blood. Terminally he developed the hepatorenal syndrome. Permission for a post-mortem percutaneous liver biopsy only was obtained. Despite some loss of cell cohesion, histological examination showed obvious micronodular cirrhosis with paren- chymal nodules separated by septa composed of fibrous tissue, proliferated bile ductules and chronic inflammatory cells (Figs. 1 and 2). There was severe intracellular and canalicular cholestasis. Several cells at the periphery of the nodules contained Mallory's hyaline (Fig. 3). Moderate quantities of orcein- and rhodanine-positive material were present in the cells at the periphery of the nodules. In view of the clinical and pathological similarities to those reported in Indian childhood cirrhosis from the Indian subcontinent, unstained sections were sent to Professor N C Nayak at the All-India Institute of Medical Sciences, New Delhi, and his report was as follows: 'Needle biopsy of the liver is partly fragmented. The hepatic architecture is completely destroyed and replaced by small nodules of parenchyma separated by cellular fibrous septa of variable width. In several nodules areas of ischaemic necrosis infiltrated by a few lymphocytes and polymorphs are seen. There is marked cellular and canalicular cholestasis, some regenerative activity in the form of double cell plates, ballooning of a few hepatocytes and the presence of both irregular and globular hyaline (Mallory bodies and megamitochondria respectively) in several liver cells. There is no excess of lipid. The fibrous septa contain ductules and a moderately large number of lymphocytes. The histological features of the biopsy are consistent with Indian childhood cirrhosis in an older child.'

Immunoperoxidase staining of liver tissue for HBsAg and HBcAg (Hepatitis B core antigen) were negative. The liver copper content was $1.97 \mu \mathrm{mol} / \mathrm{g}$ dry weight $(125 \mu \mathrm{g} / \mathrm{g})$.

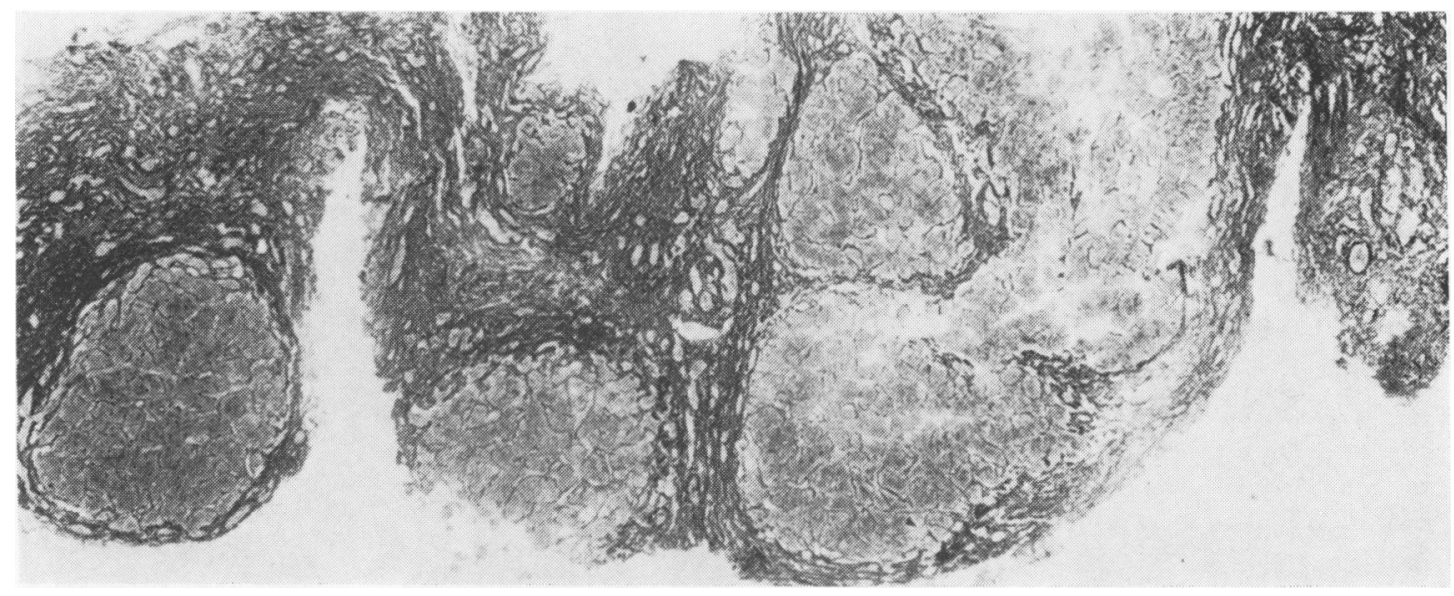

Fig. 1 Case 1. The liver shows an advanced micronodular cirrhosis with extensive fibrosis amd the biopsy is somewhat fragmented. Gordon and Sweet reticulin, $\times 85$. (Magnifications quoted in this and the following figures are original magnifications.) 


(1)

Fig. 2 Case 1. A liver cell nodule and adjacent fibrous septum. Canalicular cholestasis is just discernible (arrows) and note the absence of fatty change. The septum contains proliferated bile ductules and lymphocytes. $H$ and $E, \times 210$.

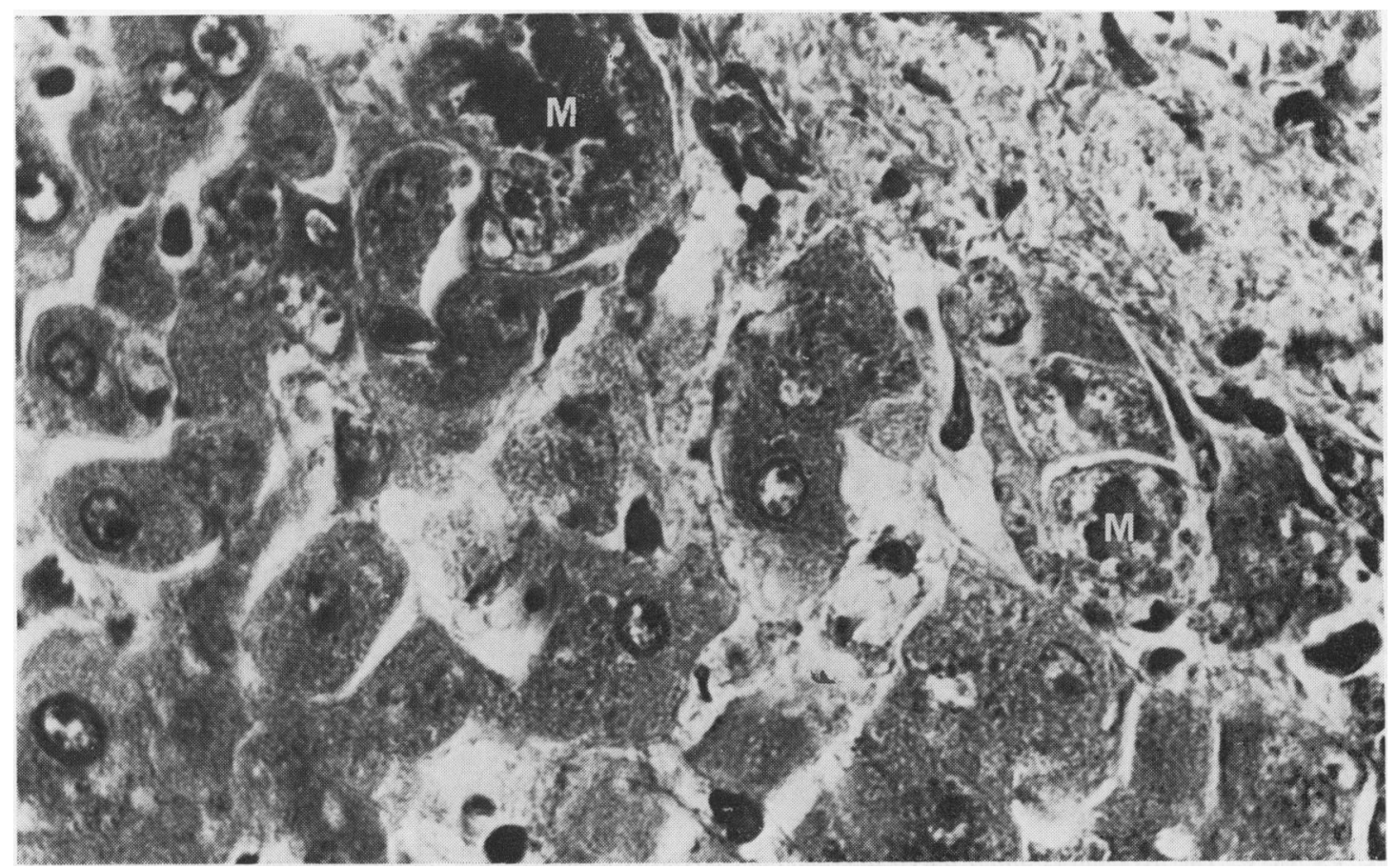

Fig. 3 Case 1. Liver cells have lost cohesion because of post-mortem autolysis and two cells contain typical Mallory's hyaline (M). Masson trichrome, $\times 800$. 
CASE 2

Abdus, the younger brother, was born in Manchester by Caesarean section. He had never been out of the UK. When first seen in April 1977, aged 5 years, he gave a history, on direct questioning, of pruritus of four years' duration together with central abdominal pain and diarrhoea for one year. He was below the third centile for height and weight with facial telangiectases but no clubbing or icterus. The liver edge was just palpable and there was a two-finger splenomegaly. Kayser-Fleischer rings were absent on slitlamp examination.

Investigations showed $\mathrm{a} \mathrm{Hb}$ concentration of $8.9 \mathrm{~g} / \mathrm{dl}$ and platelets of $123 \times 10^{9} / 1\left(123000 / \mathrm{mm}^{3}\right)$. $\mathrm{Hb}$ electrophoresis was normal. The bone age assessed radiologically lay between 36 and 42 months. Total serum bilirubin was $14 \mu \mathrm{mol} / 1$ $(0.8 \mathrm{mg} / 100 \mathrm{ml})$, asparate transaminase $62 \mathrm{IU} / 1$, alkaline phosphatase $367 \mathrm{IU} / \mathrm{l}$, albumin $39 \mathrm{~g} / \mathrm{l}$ $(3.9 \mathrm{~g} / 100 \mathrm{ml})$, and globulin $38 \mathrm{~g} / 1(3.8 \mathrm{~g} / 100 \mathrm{ml})$. The prothrombin time was 15 seconds (control 14 seconds). Serum calcium, inorganic phosphate and PTH levels were normal. The serum caeruloplasmin was raised at $0.7 \mathrm{OD}$ units. The serum iron was $8 \mu \mathrm{mol} / \mathrm{l}(44 \mathrm{mg} / 100 \mathrm{ml})$ and the iron binding capacity was $102 \mu \mathrm{mol} / 1(570 \mathrm{mg} / 100 \mathrm{ml})$. Circulating autoantibodies were absent. Serum HBsAg,
$\mathrm{HBsAb}$, and $\mathrm{HBcAb}$ were absent (RIA). The serum $\alpha_{1}$-antitrypsin concentration was $100 \%$ of average normal. Sweat electrolytes were normal. The red cell galactose-1-phosphate uridyl transferase level was normal; WR and specific viral antibody tests were negative. The $\alpha$-foetoprotein concentration was $<10 \mathrm{ng} / \mathrm{ml}$. Bone marrow examination showed no stainable iron and no infiltration with abnormal cells. Urinary mucopolysaccharides were not increased. The ferric chloride test on urine was negative. There was a non-specific amino-aciduria with no evidence of tyrosinaemia. The 24 hour urinary copper output was $0.53 \mu \mathrm{mol}(33.6 \mu \mathrm{g})$. Chromosome studies showed a normal male karyotype.

A technetium sulphur colloid liver scan showed a normal liver but an enlarged spleen with increased uptake. Grey-scale ultrasound scan showed no evidence of extrahepatic obstruction. Liver histology (needle biopsy) showed micronodular cirrhosis (Fig. 4), the nodules being separated by slender fibrous septa containing an infiltrate of lymphocytes, monocytes, and occasional neutrophils. At the nodule margins, single cells or cell groups were encircled by fibrous tongues (Fig. 5). Finely granular orcein- and rhodanine-positive material was present at the periphery of the nodules. Immunoperoxidase staining of liver tissue for $\mathrm{HBsAg}$ and $\mathrm{HBcAg}$ was negative.

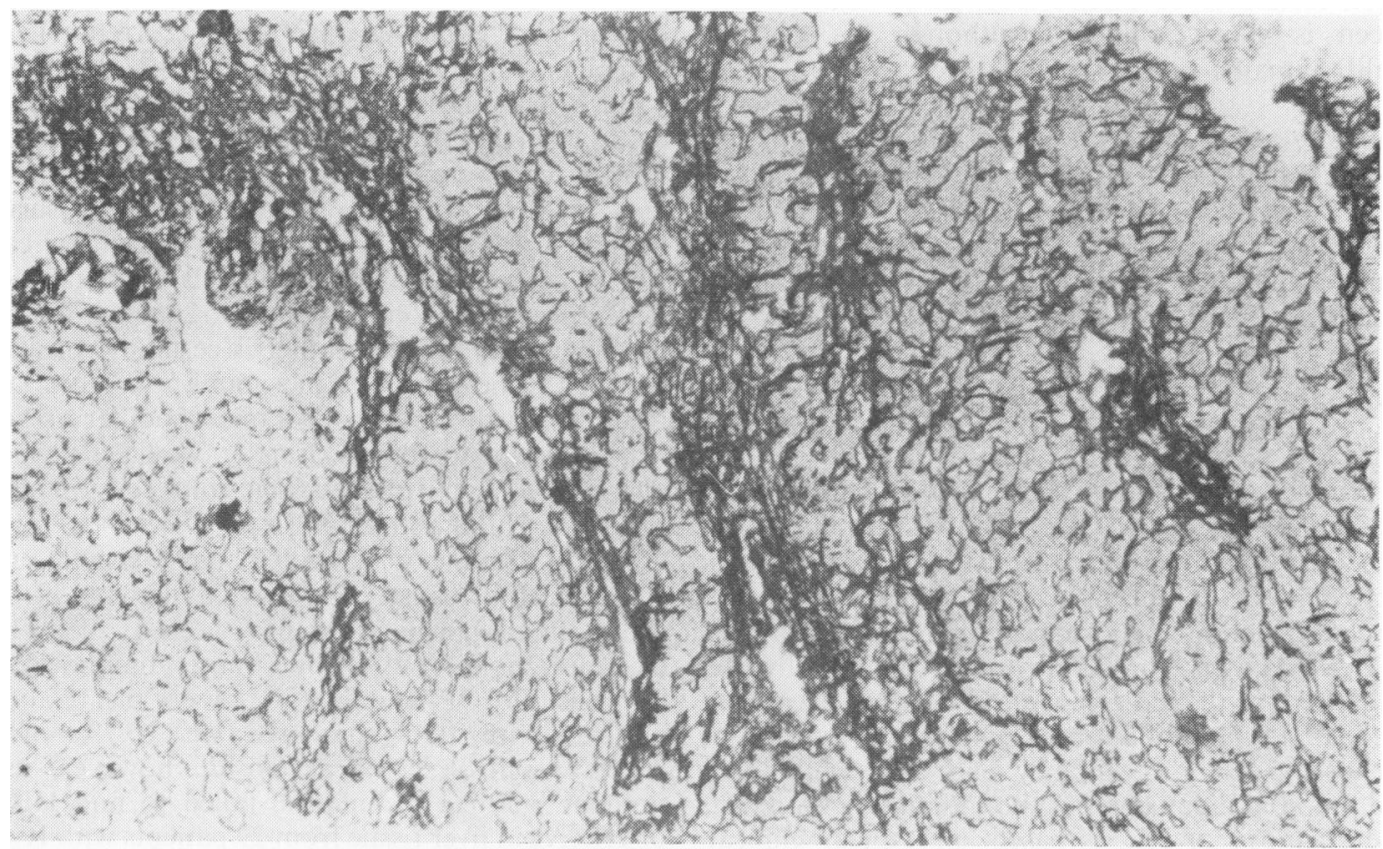

Fig. 4 Case 2. Liver architecture is disturbed by ragged fibrous septa and nodule formation. Gordon and Sweet reticulin, $\times 210$. 


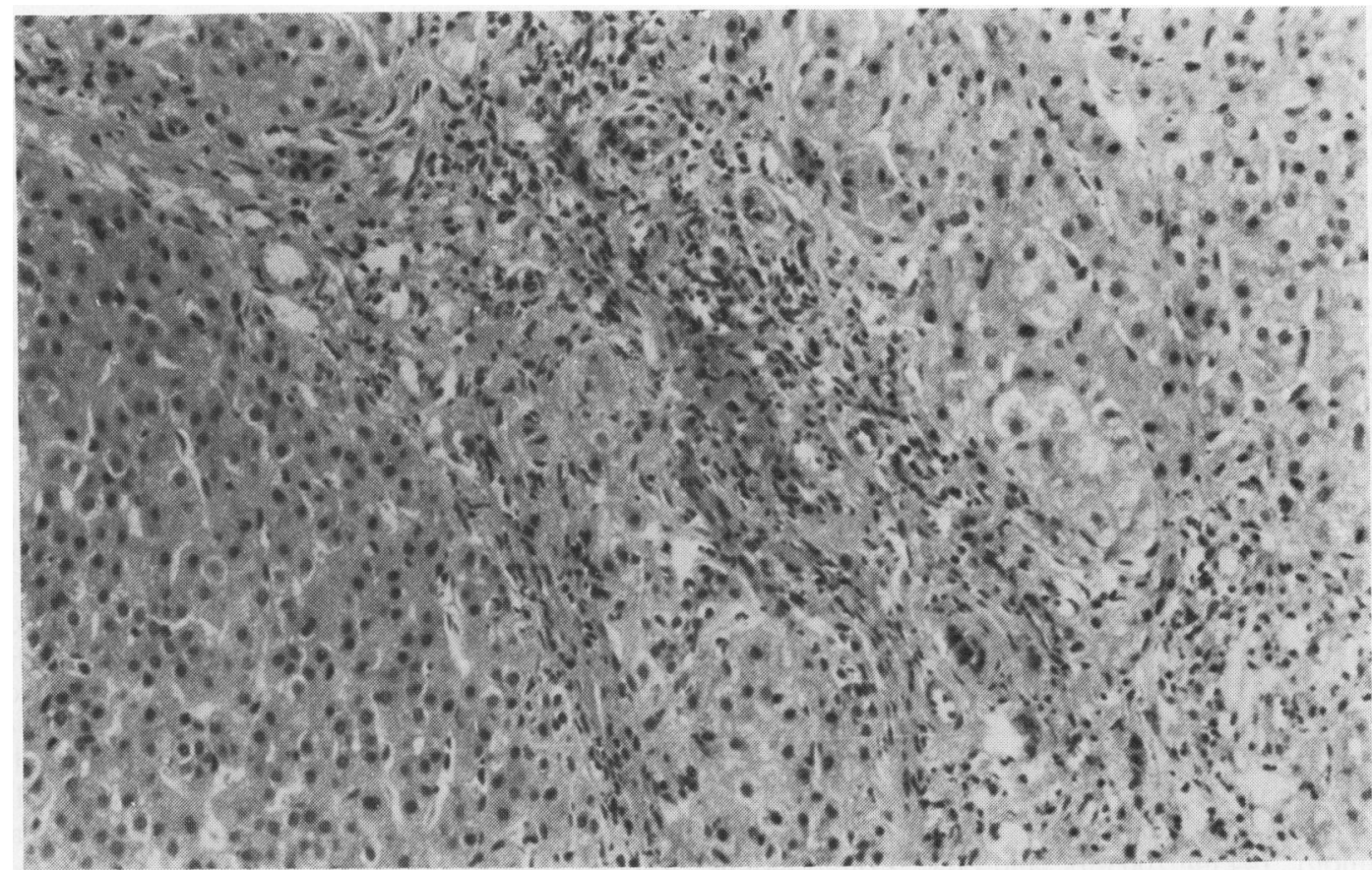

Fig. 5 Case 2. Liver cell nodules are separated by slender fibrous septa containing a moderate inflammatory cell infiltrate. The limiting plates are ragged because of active fibrosis encircling small cell groups. $H$ and $E, \times 525$.

$\mathrm{He}$ continues to attend our Liver Clinic. His spleen is slowly enlarging although his general health remains good.

\section{Family history}

The parents are first cousins. Clinical and biochemical studies in them, in their other two children (girls aged 1 and 4 years), and in the maternal grandmother have not revealed any evidence of liver disease.

\section{Discussion}

In the UK the familial occurrence of cirrhosis is uncommon except in association with a number of hereditary metabolic disorders. Cirrhosis may also supervene in familial 'giant-cell hepatitis', ${ }^{6}$ and familial cholestatic syndromes of infancy. ${ }^{7}$ A number of kindreds with familial cirrhosis presenting in late childhood and adolescence have also been described. ${ }^{8}$ Indian childhood cirrhosis is a variety of cirrhosis peculiar to infancy and early childhood and found in many parts of the Indian subcontinent. The diagnosis of ICC is based on typical clinical features, characteristic histology, and the exclusion of other causes of childhood cirrhosis. In our two patients, the clinical picture of appropriate racial background, insidious onset and occurrence in the two older children (both male) conforms to the typical pattern. Although the usual age at presentation is said to be 1-3 years of age, previous cases have been described who were more than 5 years old when first seen. $^{35}$ Moreover, on the basis of a field survey, Parekh and Patel ${ }^{9}$ suggest that asymptomatic cases with hepatomegaly and disturbed liver function tests may range in age from $2 \frac{1}{2}$ months to 21 years. The liver histology of the older brother is certainly consistent with ICC; the biopsy of the younger brother lacks Mallory's hyaline but shows a micronodular cirrhosis with pericellular fibrosis. Finally, we have excluded alternative infective, metabolic and developmental causes of childhood cirrhosis.

It is not known whether ICC has a genetic or an environmental cause. However, a number of biochemical abnormalities have been described. Chandra found $\mathrm{HBsAg}$ by counterimmunoelectrophoresis (CIEOP) and RIA in the sera of $11 \%$ of his patients with ICC compared with $0.7 \%$ of his healthy controls. ${ }^{10}$ Nayak et al., however, using immune staining techniques, failed to find $\mathrm{HBsAg}$ or $\mathrm{HBcAg}$ in liver tissue from 29 patients with $\mathrm{ICC}^{11}$; in only one patient did orcein staining reveal orceinpositive material suggestive of, although not entirely 
conforming to, the morphology of HBsAg; and none of his sera was positive for HBsAg (CIEOP). Our results do not favour a role for the hepatitis B virus in the aetiology of ICC.

Nayak et al. found $\alpha$-foetoprotein measured by gel diffusion to be present in $52 \%$ of his patients. ${ }^{12}$ Chandra, using RIA, found $100 \%$ to be positive. ${ }^{10}$ Both our cases were negative by RIA.

Recently, it has been claimed that disordered tryptophan metabolism may play an important role in the pathogenesis of ICC, after the demonstration of raised levels of tryptophan metabolites (notably 3-hydroxyanthranilic acid) in the urine of a group of 23 patients with ICC. ${ }^{5}$ All members of this group, unlike our two patients, had positive urinary ferric chloride tests.

Coarse orcein-positive granules have been demonstrated in the cytoplasm of liver cells in many cases of ICC. ${ }^{11}$ The staining pattern differed from that produced by hepatitis B virus. This finding has recently been confirmed ${ }^{13}$ and it has been suggested that the orcein-positive material, which stained with the copper-specific stains rubeanic acid and rhodanine, represents copper-binding protein. Accordingly, it was postulated that ICC may be a copper storage disorder. However, no data on serum, urine, or liver copper has yet been reported. In the liver cells of our two patients, the orcein-positive granules were less marked than in the Kings' series. ${ }^{13}$ Furthermore, while the liver copper concentration in the older brother was raised at $1.97 \mu \mathrm{mol} / \mathrm{g}(125 \mu \mathrm{g} / \mathrm{g})$ of dry liver, this level is much lower than is found in the two liver disorders in which excess copper storage is thought to play a pathogenetic role-namely, Wilson's disease ${ }^{14}$ and primary biliary cirrhosis. ${ }^{15}$

It is apparent that no single biochemical abnormality has been consistently found. Indian childhood cirrhosis may therefore represent a heterogeneous group of disorders with certain clinical and histological features in common. Moreover, residence outside the Indian subcontinent may modify these features.

The first example of an immigrant child with Indian childhood cirrhosis presenting in the UK has recently been reported. ${ }^{16}$ This 10 month old child had developed the disorder in India, dying shortly after arrival in the United Kingdom. In the present report, the older boy had been born in Bangladesh and had come to this country with his family at the age of 4 years. However, the younger boy was born in the UK and has never been abroad. He represents the first example of ICC born in the UK. Our two cases suggest that the disease is likely to have a genetic rather than an environmental cause and can occur in Asian children born and brought up in the UK. It is likely that other cases of ICC will be recognised in the Asian populace in the UK and it is important that the diagnosis of ICC is considered in any child of appropriate background who presents with chronic liver disease in the UK.

We thank Dr D McCauley and Dr R Harris for referring the patients; Dr D Patrick, Institute of Child Health, for performing the red and white cell enzyme assays which excluded glycogen storage diseases; Professor N C Nayak, All-India Institute of Medical Sciences, for his opinion on the liver histology; and Dr I Sardharwalla, Willink Biochemical Genetics Unit, Royal Manchester Children's Hospital, for the urine and serum chromatograpiny.

\section{References}

${ }^{1}$ Mohan M, Bhargava SK, Sobti JC, Taneja PN. Indian childhood cirrhosis, a heredo-familial disease. Indian Pediatr 1967; 4: 125-31.

${ }^{2}$ Katiyar GP, Dikshit SK. Indian childhood cirrhosis, a heredo-familial disorder. Indian Pediatr 1972; 9: 349-53.

${ }^{3}$ Nayak NC, Visalakshi S, Singh M, Chawla V, Chandra RK, Ramalingaswami V. Indian childhood cirrhosis-a re-evaluation of its pathomorphologic features and their significance in the light of clinical data and natural history of the disease. Indian J Med Res 1972; 60: 246-59.

${ }^{4}$ Warnes TW, Hine P, Kay G. Polyacrylamide gel disc electrophoresis of alkaline phosphatase isoenzymes in bone and liver disease. J Clin Pathol 1976; 29: 782-7.

${ }^{5}$ Sur AM, Bhatti A. Indian childhood cirrhosis: an inherited disorder of tryptophan metabolism? Br Med J 1978; 2: 529-31.

${ }^{6}$ Greco MA, Finegold MJ. Familial giant-cell hepatitis. Arch Path 1973; 95: 240-4.

${ }^{7}$ Mathis RK, Andres JM, Walker WA. Liver disease in infants. Part 2. Hepatic disease states J Pediatr 1977 90: 864-80.

${ }^{8}$ Maddrey WC, Iber FL. Familial cirrhosis, a clinical and pathological study. Ann Intern Med 1964; 61: 667-79. ${ }^{9}$ Parekh SR, Patel BD. Epidemiologic survey of Indian childhood cirrhosis. Indian Pediatr 1972; 9: 431-9.

${ }^{10}$ Chandra, RK. Indian childhood cirrhosis: genealogic data, alphafoetoprotein, hepatitis antigen and circulating immune complexes. Trans R Soc Trop Med Hyg 1976; 70: 296-301.

${ }^{11}$ Nayak NC, Ramalingaswami V, Roy S, Sachdeva R. Hepatitis-B virus and Indian childhood cirrhosis. Lancet 1975; 2 : 109-11.

${ }^{12}$ Nayak NC, Malaviya AN, Chawla V, Chandra RK. Alphafetoprotein in Indian childhood cirrhosis. Lancet 1972; 1 : 68-9.

${ }^{13}$ Portmann B, Tanner MS, Mowat AP, Williams R. Orcein-positive liver deposits in Indian childhood cirrhosis. Lancet 1978; 1: 1338-40. 
${ }^{14}$ Sternlieb, I. Evolution of the hepatic lesion in Wilson's disease (hepatolenticular degeneration). In: Popper $\mathrm{H}$, Schaffner F, eds. Progress in liver diseases, Vol. 4. New York and London: Grune and Stratton, 1972 511-25.

${ }^{15}$ Fleming CR, Dickson ER, Bagenstoss AH, McCall JT.
Copper and primary biliary cirrhosis. Gastroenterology 1974; 67: 1182-7.

${ }^{16}$ Tanner MS, Portmann B, Mowat AP, Williams R. Indian childhood cirrhosis presenting in Britain with orcein-positive deposits in liver and kidney. $\mathrm{Br} \mathrm{Med} \mathrm{J}$ 1978; 2: 928-9. 